Arch. histol. jap. Vol. 24, n. 3 (February 1964). P. $273-283$.

Dept. of Intern. Med. (Head: Prof. K. HIRAKI), Okayama Univ. Med. Sch., Oka, Okayama.

\title{
Electron Microscopic Observation on the Virus Particle of Japanese B Encephalitis Propagated in PS Cells.
}

PS 細胞に増殖した日本脳炎ウィルス粒子の電子顕微鏡的観察.

\section{Zensuke OTA, Sinya SUZUKI, Kenji TAKAHASHI and Masahito MUGURUMA}

太田善介，鈴木信也，高橋建次，六車昌士.

(Received February 4, 1964.)

Although the etiological agent of Japanese B encephalitis (JBE) was proved to be virus in 1635 by HAYASHI, the morphological characteristics and developmental process of the virus particles in host cells have been unknown.

The size of JBE virus particle was reported to be 10 to $30 \mathrm{~m} \mu$ in diameter by the gradocol membrane method (YAOI et al. 1939). Recent electron microscopic observations by means of shadow-casting and thin sectioning have revealed that the virus particles are 30 to $50 \mathrm{~m} \mu$ in diameter and round or hexagonal in shape (FUKAI 1962, OTA et al. 1963, HIGASHI 1963).

It is the purpose of this communication to present an electron microscopic observation on the ultrastructure and mode of development of JBE virus propagated in vitro on porcine kidney stable (PS) cells. The development of virus paiticles in PS cells was also analysed in one-step growth experiment.

\section{Materials and Methods.}

Both the JBE virus (the MUKAI strain) and PS cells used were kindly supplied by Dr. KANDA INOUE at the Virus Institute of Kyoto University where these virus and cells have been used for biological investigation.

Tissue culture method was essentially the same as that used by KANDA INOUE and his co-workers (KANDA INOUE and OGURA 1962, KATO and KANDA INOUE 1962). Monolayer of PS cells was grown in bottles containing $10 \%$ calf serum and $0.5 \%$ lactalbumin hydrolyzate in EARLE's balanced solution. For virus propagation, PS cells of 3 to 5 day cultnre (approximately $15 \times 10^{4}$ cells per ml) received virns inoculum of about $10^{6}$ TCID $_{50}$ that was prepared by centrifuging culture fluid after nearly all of the cells showed cytopathic effect. Incubation temperature was $36^{\circ} \mathrm{C}$.

Titration of cell-associated virus was estimated 5 days after infection by cytopathic effect. The results obtained are shown in Fig. 1.

At 8 to 24 hours after infection, bottle-cultured PS cells were tripsinized and centrifuged. The resultant pellets were fixed for 40 minutes at $4^{\circ} \mathrm{C}$ in buffered $1 \%$ osmium tetroxide solution, and after dehydration, embedded in methacryates. The sections were stained in saturated uranyl acetate solution. Observations were performed 


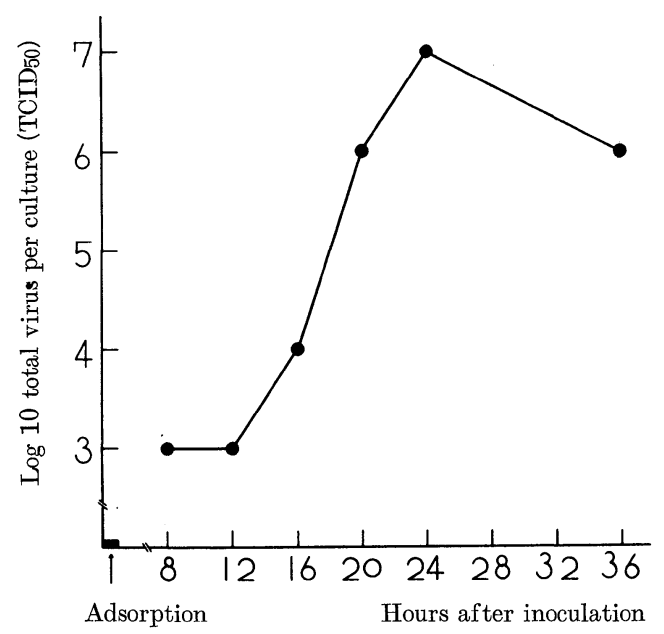

Fig. 1. Growth curve of cell-associated JBE virus in PS cells.

in the Hitachi type HU 11 electron microscope.

\section{Results.}

\section{A. Uninfected PS cell.}

PS cells of 3 to 5 day culture were used for virus propagation. During this period, uninfected PS cells are actively growing without displaying degenerative changes in their ultructure. The uncleus is round and the nucleoli are promint. In the cytoplasm, the mitochondria, endoplasmic reticulum and vacuoles are scattered. There are a few cytoplasmic protrusions on the cell surface.

\section{B. Infected PS cell and JBE virus particle.}

JBE virus particles could be observed 18 to 24 hours following infection.

a) Formation and Liberation of JBE virus particle.

Figs. 2 and 3 show the eariest stage of development of JBE virus particles. Virus particles are budding from the wall of the cytoplasmic vacuoles located near the central region of the PS cells. In Fig. 4, virus particles are connected with the vacuolar wall by a pedicle. These findings clearly show that the formation of JBE virus particles takes place on the surface of the cytoplasmic vacuole.

Fig. 5 displays the following stage. The cytoplasmic vacuoles are densely packed with numerous virus particles, each of which has unequivocal characteristics of virus particles. At this stage, virus particles can be arranged in a crystalline array as seen in Fig. 6. In crystal, the average spacing of virus particles measures $40 \mathrm{~m} \mu$.

Then, the vacuoles packed with virus particles enlarge and move in the cytoplasm toward the cell surface (Fig. 7) and liberate virus particles outside the cell through a narrow canaliculus which is formed between the vacuole and cell surface 
(Fig. 9). On liberation, the virus particles do not undergo any morphological changes. This indicates that the virus particles observed within the vacuoles are complete mature virus particles.

b) Morphology of JBE virus particle.

The shape of the majority of JBE virus particles is found to be oval. Some of the virus particles which have sufficiently retained their original shape are hexagonal (Fig. 8). The longest diameter measures $40 \mathrm{~m} \mu$ and the shortest $32 \mathrm{~m} \mu$ in average. The particles are composed of the outer membrane, viroplasm and an electron-dense nucleoid. The outer membrane and viroplasm surrounding the nucleoid, measure $20 \AA$ and $30 \AA$ in thickness, respectively, and the nucleoid measures $25 \mathrm{~m} \mu$ in the longest diameter. Virus particles seen in Fig. 8 suggest double-layer structure of the outer membrane and the presence of inner membrane around the nucleoid.

c) Other findings.

Some interesting changes are seen in infected PS cells. In Fig. 7, empty particles composed of double membrane are seen within the cytoplasmic vacuoles. They bud at the vacuolar wall and are often connected with it by a pedicle. It may be, therefore, probable that this structure represents the incomplete virus particle.

A large amount of filament and numerous, electron-dense fine granules $180 \AA$ in diameter are frequently seen in the cytoplasm in close association with the virus-containing vacuoles (Fig. 10). Enlarged mitochondria, onion skin-like structure, and honeycomb structure are also observed in the cytoplasm and small aggregates of electron-dense granules in the nucleus (Fig. 11).

\section{Discussion}

The size of JBE virus is found to be approximately $40 \mathrm{~m} \mu$ in diameter. This value agrees with our previous study (OTA et al. 1963) on JBE virus particles and several other observations previosly described and is similar to the size of western equine encephalitis (45-48m $\mu$, MORGAN et al. 1961) and Venezuelan equine encephalitis virus ( $40-48 \mathrm{~m} \mu$, MUSSGAY and WEIBEL, 1962) of arthropod-borne encephalitis gronp.

Intracelluar crystallization of virns particles has been observed in animal viruses as well as plant viruses. Notable examples are adenovirus, KJELLÉN et al. 1955, MORGAN et al. 1956), herpes simplex virus (MORGAN et al. 1959), poliomyelitis virus (STUART and FOGH 1959) etc. In the MUKAI strain of JBE virus, crystallization is rather a rare phenomenon. The average spacing of JBE virus particles in crystal is approximately $40 \mathrm{~m} / \mathrm{w}$ wich is nearly equal to the average diameter of the virus particle. 'Therefore, the virus particles forming crystals are supposed to be mature virus particlss.

In JBE virus, numerous virus particles are packed in the cytoplasmic vacuoles of PS cells. This type of localization of virus particles has also been observed in western equine encephalitis virus (MORGAN et al. 1961) and Venezuelan equine encephalitis virus (MUSSGAY and WEIBEL 1962). In western equine encephalitis, intracytoplasmic granules mature into virus particles at the wall of cytoplasmic vacuoles. In the present observation on JBE virus, snch a phenomenon has not been sufficiently 
demonstrated except for some suggestive findings. It is certain, however, that the synthesis of viral components or precursors of mature virus particles takes place within the cytoplasm and possibly also in the nucleus, since by fluorescent antibody method, specific fluorecence has been observed in the cytoplasm and also in the nucleus, as previously reported (OTA et al. 1963). Intranuclear aggregates of fine, electron-dense granules observed in the present investigation might represent the precursors of JBE virus particles. Recently, MORGAN et al. (1962) have proved by ferritin-conjugated antibody method that simillar intranuclear granules have viral antigenicity in influenza.

\section{Summary.}

An electron microscope study was performed on the ultrastructure and developmental process of the MUKAI strain of Japanese B encephalitis virus propagated in vitro on porcine kidney stable cells.

Tne virus particle of Japanese B encephalitis is hexagonal in sections and approximately $40 \mathrm{~m} \mu$ in the longest diameter, composed of the outer mambrane, $20 \AA$ thick, viroplasm, $30 \AA$ thick and an electron-dense nucleoid, $25 \mathrm{~m} \mu$ in diameter. The virus particles develop by budding process on the wall of the cytoplasmic vacuole. Thereafter, virus particles are densely packed in the vacuole usually in random arrangement and rarely in crystalline arrays. The vacuole containing virus particles gradually moves toward the cell surface and liberates the virus particles to the exterior of the cells through a narrow canaliculus.

A structure suggestive of incomplete virus particles was also observed.

\section{内 容自抄.}

PS 細胞（豚腎継代細胞）を用いて日本脳炎ウィルス向井株を増殖させ，日本脳 炎ウィルス粒子の形態, 細胞内増殖の過程を超薄切片法により電顕的に追究した.

日本脳炎ウィルス粒子は切片上で一方向に長い六角形であり, その長径は平均 $40 \mathrm{~m} \mu$, 外膜, ウィロプラスムおよび中心部にある直径 $25 \mathrm{~m} \mu$ の電子密度の高い核 様体より成る。乙の粒子は SP 細胞の細細質内にある空胞壁より形成され, 空胞 内に充満し, 一部は結晶を形成し, 空胞に含まれたまま細胞辺縁部に移動して, 細 管を通じて細胞外に放出される。乙の際ウィルス粒子は形態的変化を受けない.

なお不完全ウィルス粒子と思われる構造屯観察された。

\section{References.}

Hayashi, M.: Übertragung des Virus von Encephalitis epidemica auf Affen. Folia psych. et neurol. jap. 1 (1935). P. 419-465. - Kanda Inoue, Y. and R. Ogura : Studies on Japanese B encephalitis virus. III. Propagation and assay of Japanese B encephalitis virus in a stable line of porcine kidney stable cells. Virology 16 (1962). P. 206-207. — Kato, H. and Y. Kanda Inoue: Studies on Japanese B enecphalitis virus. IV. Plaque assay of Japanese B encephalitis in a stable line of porcine kidney cells. Virology 18 (1962). P. 500-501. - Kjellén, L., G. Lagermalm, A. Svedmyr and K. G. Thorsson: Crystalline-like paterns in the nuclei of cells 
infected with an animal virus. Nature 175 (1955). P. 505-506. - Morgan, C., C. Howe, H. M. Rose and D. H. Moore: Structure and development of viruses observed in the electrom microscope. IV. Viruses of the RI-APC group. J. Biophys. Biochem. Cytology 2 (1956). P. 351-360. - Morgan, C., H. M. Rose, M. Holden and E. P. Jones : Elcctron microscopic observation on the development of herpes simplex viruses. J. exptl. Med. 110 (1956). P. 643-656. - Morgan, C., C. Howe and H. M. Rose: Structure and development of viruses as observed in the electron microscope. V. Western equine encephalitis virus. J. exptl. Med. 113 (1961). P. 219-234. - Morgan, C., R. A. Rikind and H. M. Rose: The use of ferrition conjugated antibodies in electron microscopic study of influenza and vaccinia viruses. Cold Spring Harbor Symposia Quant. Biol. 27 (1962). P. 27-65. - Mussgay, M. and T. Weibel : Electron microscopic and biological studies on the growth of Venezuelan equine encephalitis virus in KB cells. Virology 16 (1962). P. 52-62. -Ota, Z., T. Kotsuka, M. Kahara and K. Takahashi : A study of Japanese B encephalitis virus by fluorescent antibody method and electron micrcscopy. Jap. J. clin. Med. 21 (1963). P.19391952. - Stuart, D. C. and J. Fogh : Electron microscopic demonstration of intracellular polivirus crystals. Exptl. Cell Research 18 (1959). p. 378-381. - Yaoi, H., K. Kanazawa, M. Murai and S. Arakawa: On size of Japanese epidemic encephalitis virus as estimated by 'gradocol' membrane. Jap. J. exptl. Med. I7 (1939). P. 375-378. 


\section{Explanation of Plate-Figures.}

Fig. 2. 21.5 hours after infection. JBE virus particles, developing in multiple foci (arrows), are seen in small cytoplasmic vacuoles. The eariest stage of virus development. $m$ mitochondria. $\times 50,000$

Fig. 3. 21.5 hours after infection. Portion of Fig. 2 at higher magnification. Virus particle $(v p)$ budding at the vacuolar wall. Note the outer membrane of the virus particle is continuous with the vacuolar wall (arrow). $\times 170,000$

Fig. 4. 19 hours after infection. Arrows point to pedicles connecting the virus particle and vacuolar wall. $\times 130,000$ 

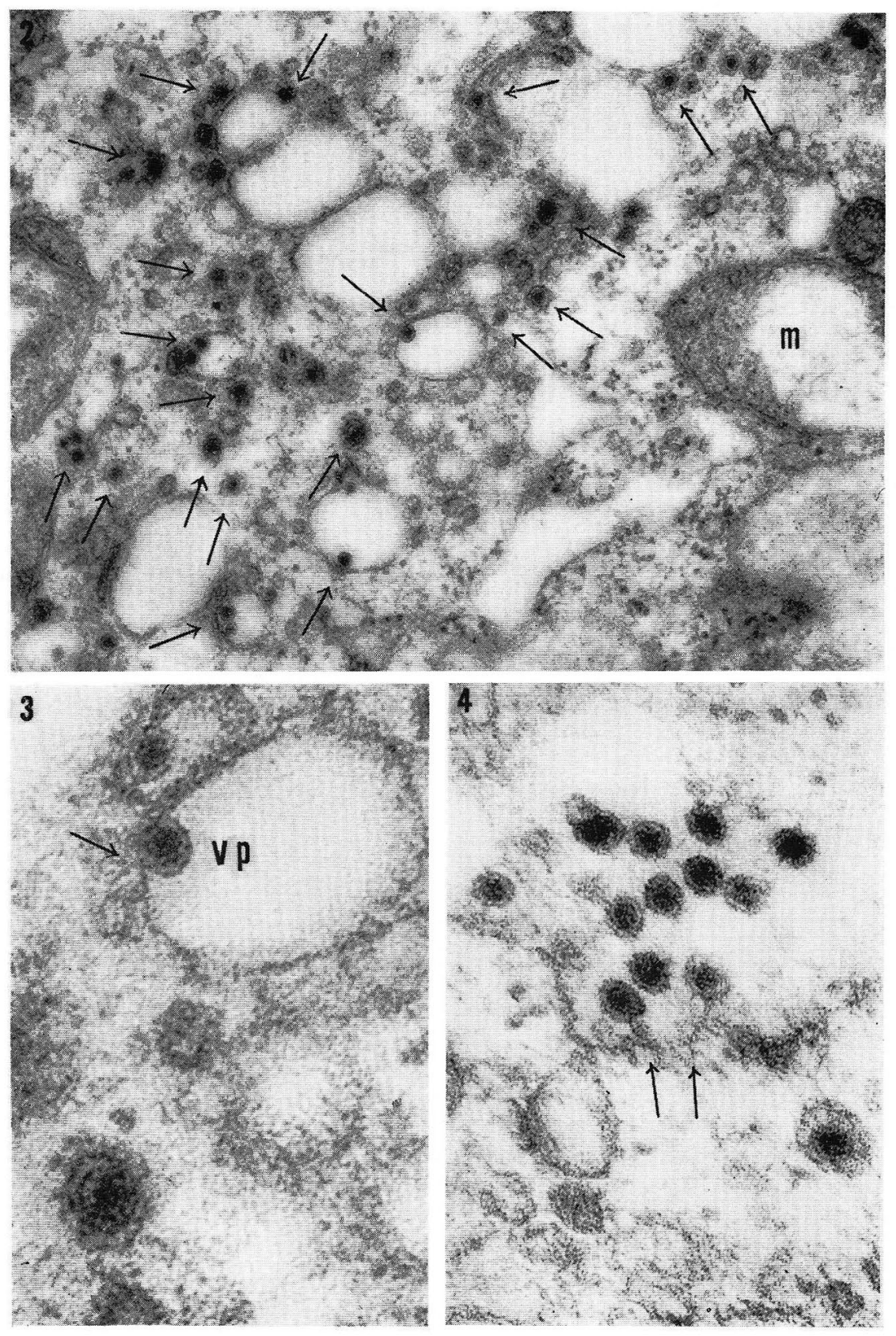
Fig. 5. 21.5 hours after infection. Virus particles packing the cytoplasmic vacuole. $\times 140,000$

Fig. 6. 21.5 hours after infection. Crystalline arrays of virus particle $(c)$ in the cytoplasmic vacuoles. $\times 53,000$

Fig. 7. 21.5 hours after infection. Scattered virus particles $(v p)$ and empty particle $(e p)$ composed of double membrane are contained in enlarged vacuoles. Arrow indicates a pedicle connecting the empty particle and vacuolar wall. $\times 50,000$ 

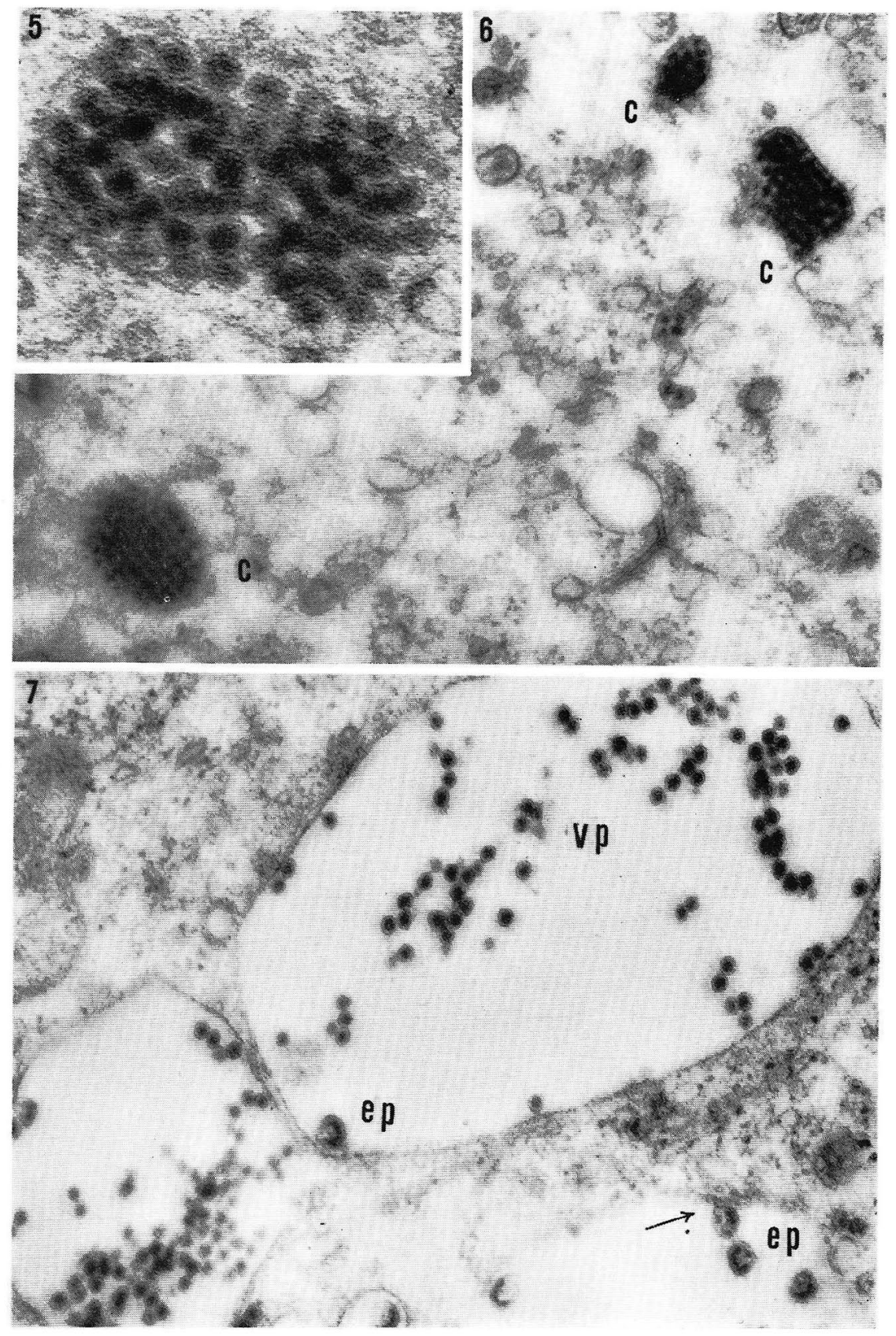
Fig. 8. 21.5 hours after infection. Portion of Fig. 7 at higher magnification. The outer membrane, viroplasm and nucleoid of the virus particle are clearly seen. Arrows point to virus particles hexagonal in shape. Their outer membrane shows double-layer structure. $\times 170,000$

Eig. 9. 21.5 hours after infection. Intracellular and extracellular virus particles. Arrow indicates a canaliculus connecting the vacuole and cell surface. $\times 50,000$

Fig. 10. 19 hours after infection. Numerons fine grauules $(f g)$ and filaments $(f)$ seen in the infected PS cell. Some of granules are arranged in parallel rows (arrow). $\times 50,000$

Fig. 11. 19 hours after infection. Intranuclear aggregates of fine, elecrotn-dense granules (g). $n$ nucleous. $\times 50,000$ 
Z. OTA, S. SUZUKI, K. TAKAHASHI and M. MUGURUMA (3)
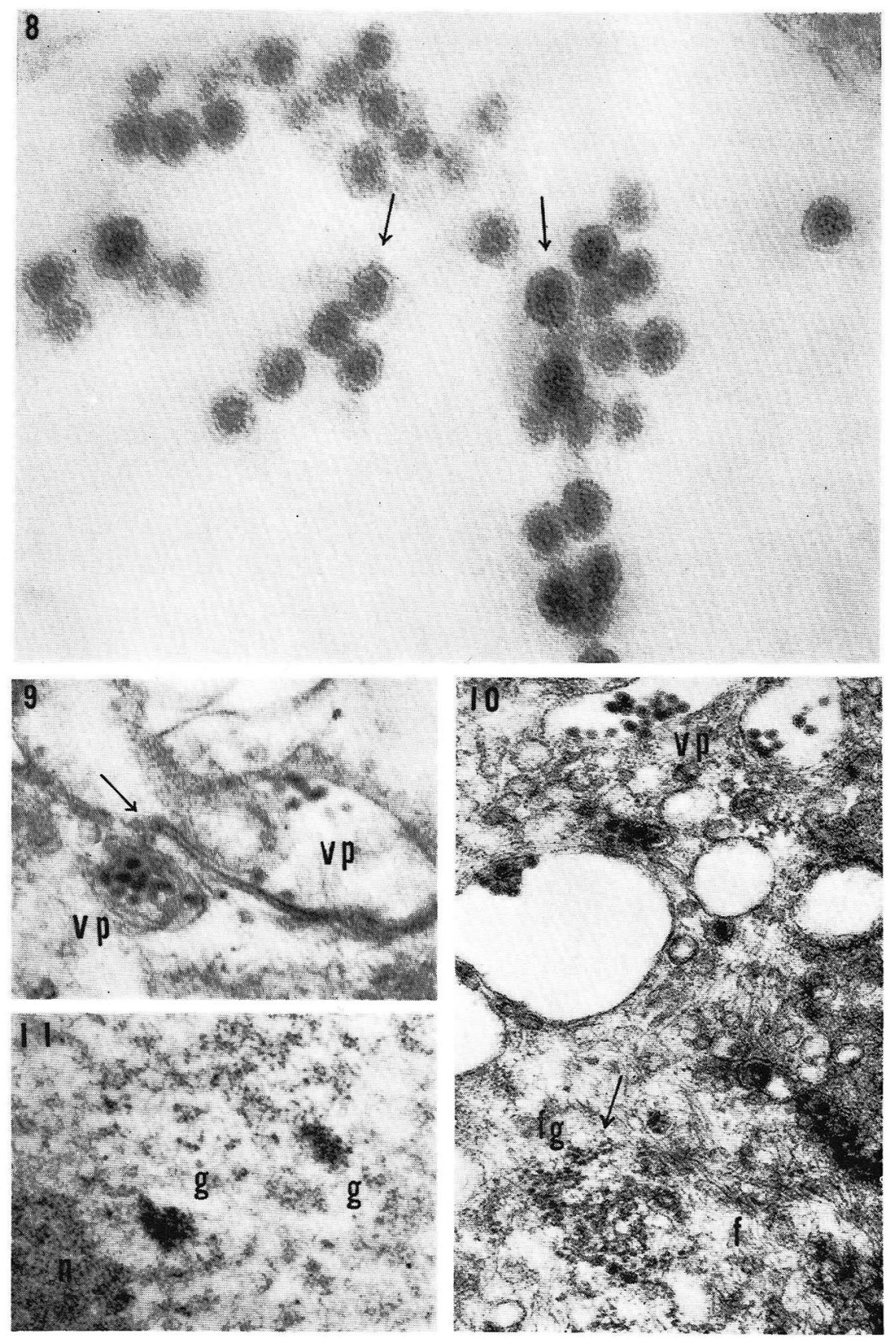